\title{
Extracellular vesicle-derived miRNA as a novel regulatory system for bi-directional communication in gut-brain-microbiota axis
}

\author{
Liang Zhao ${ }^{1}$, Yingze Ye ${ }^{2}$, Lijuan $\mathrm{Gu}^{2}$, Zhihong Jian ${ }^{2}$, Creed M. Stary ${ }^{3^{*}}$ and Xiaoxing Xiong ${ }^{2^{*}}$
}

\begin{abstract}
The gut-brain-microbiota axis (GBMAx) coordinates bidirectional communication between the gut and brain, and is increasingly recognized as playing a central role in physiology and disease. MicroRNAs are important intracellular components secreted by extracellular vesicles (EVs), which act as vital mediators of intercellular and interspecies communication. This review will present current advances in EV-derived microRNAs and their potential functional link with GBMAx. We propose that EV-derived microRNAs comprise a novel regulatory system for GBMAx, and a potential novel therapeutic target for modifying GBMAx in clinical therapy.
\end{abstract}

Keywords: Exosomes, MiRNAs, MiRs, Inter-cellular communication, GBMAx

\section{Background}

The bidirectional communication and crosstalk between the gut and brain has been well recognized, termed the "gut-brain axis" [1-3]. Emerging evidence implicates gut microbiota in playing a pivotal role in the bidirectional communication that occurs in the gut-brain axis [4], leading to the more recent concept of the "gut-brainmicrobiota axis" (GBMAx). Notably, this tripartite axis is coordinated by classical neuro-immune-endocrine and metabolic pathways [4], however the molecular regulation of GBMAx remains undetermined.

MicroRNAs (miRNAs) are small, non-coding RNA molecules capable of modulating gene expression at post-transcriptional level [5]. As an important intracellular component of extracellular vesicles (EVs) miRNAs can be secreted by and transferred to varied target cells [6]. Acting as a vital mediator of intercellular communication, EV-derived miRNAs have been implicated in

\footnotetext{
*Correspondence: cstary@stanford.edu; xiaoxingxiong@whu.edu.cn ${ }^{2}$ Central Laboratory, Renmin Hospital of Wuhan University, Wuhan, China

${ }^{3}$ Department of Anesthesiology, Perioperative and Pain Medicine, Stanford University School of Medicine, Stanford, CA 94305, USA

Full list of author information is available at the end of the article
}

microbiome-host communication $[7,8]$. This review will present the current advances on EV-derived miRNAs and their functional link with GBMAx bi-directional communication. We propose that EV-derived miRNAs represent a novel regulatory system for GBMAx and a potential therapeutic target to modulate GBMAx function.

\section{The gut-brain-microbiota axis (GBMAx)}

The gut-brain-microbiota axis is composed of the following essential components: (1) the neural network, including central nervous system (CNS) the autonomic nervous system (ANS) and enteric nervous system (ENS); (2) the hypothalamic-pituitary-adrenal axis (HPA); (3) neuroendocrine networks including neurotransmitters, hormone and neuropeptides; (4) gut microbiota and their metabolic products; (5) the gut immune system; and, (6) the intestinal barrier and blood-brain barriers [9-14]. Gut microbiota are considered to be a relatively independent and varied mediator of GBMAx, which interact with other components via several neuroanatomic, neuroendocrine, enteroendocrine, neuroimmune and metabolic pathways [15].

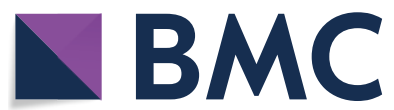

(c) The Author(s) 2021. This article is licensed under a Creative Commons Attribution 4.0 International License, which permits use, sharing, adaptation, distribution and reproduction in any medium or format, as long as you give appropriate credit to the original author(s) and the source, provide a link to the Creative Commons licence, and indicate if changes were made. The images or other third party material in this article are included in the article's Creative Commons licence, unless indicated otherwise in a credit line to the material. If material is not included in the article's Creative Commons licence and your intended use is not permitted by statutory regulation or exceeds the permitted use, you will need to obtain permission directly from the copyright holder. To view a copy of this licence, visit http://creativeco mmons.org/licenses/by/4.0/. The Creative Commons Public Domain Dedication waiver (http://creativecommons.org/publicdomain/ zero/1.0/) applies to the data made available in this article, unless otherwise stated in a credit line to the data. 


\section{Gut microbiota-miRNA interaction miRNA-biogenesis and function}

A primary miRNA transcript (pre-miRNA) can be processed by several biogenesis procedures to form the miRISC (miRNA-associated RNA-induced silencing complex) [16-19]. miRISC is then guided to target mRNA by complementary base pairing between the target sequence (TS) of the miRNA (nucleotides 2-8 in the 5'-end of the miRNA) and its target site in the 3 '-untranslated region (UTR) of target mRNAs [20, 21]. Target gene expression can be down-regulated by either translational inhibition or mRNA degradation according to the extent of base pairing and the surrounding sequences of the TS [22]. Alternatively, some studies also demonstrate that miRNAs can up-regulate transcription of certain target mRNA [23-25]. Notably, a single miRNA can potentially target multiple mRNA, whereas one mRNA can be potentially targeted by multiple miRNAs, reflecting the complex regulatory function of miRNAs [16]. Recent methodological advances including miRNA profiling and loss-of-function studies enable high-fidelity analysis of bioinformation to better define the dynamic expression and functional link with various cellular process and biological pathways in diverse tissues and from diverse species [18, 26, 27]. MiRNAs have been identified as promising candidates for biomarkers and therapeutic targets in a variety of diseases [28].

\section{Gut miRNA regulate gut microbiota}

In 2016, Liu et al. first profiled miRNA expression patterns within feces and gut luminal contents from mice and humans [7]. Intestinal epithelial cells (IEC) and homeobox gene (Hopx)-positive cells were identified as the major cellular source of fecal miRNAs. In vitro studies with cultured Fusobacterium nucleatium and Escherichia coli demonstrated that fecal miRNA could regulate bacterial gene transcripts and growth [7]. Targeted deletion of the miRNA biogenesis enzyme Dicer in mice resulted in imbalanced gut microbiota and exacerbated dextran sulfate sodium- (DSS) induced colitis, which was reversed by fecal miRNA transplantation from wild-type littermates, strongly suggesting a critical role of fecal miRNA in shaping gut microbiota and maintaining intestinal homeostasis [7].

More recent studies support an essential role of gut miRNA in inducing dysbiosis related to various disease states. In ovariectomized (OVX) mice, intestinal and fecal miR155/let-7 g expression were increased and associated with altered gut microbiota and cardiovascular function [29]. In another mouse model of total abdominal irradiation (TAI), the expression level of miR-34a-5p was elevated in small intestine, which closely correlated with composition shifting of gut microbiota, possibly contributing to associated cognitive impairment [30]. Distinct fecal or intestinal miRNA expression profiles and their potential link with disease and the abundance of gut microbiota have been identified in inflammatory bowel disease and colorectal cancer, underlying their potential clinical relevance as biomarkers or therapeutic targets [31, 32].

\section{Gut microbiota regulate gut miRNA expression}

The evidence regarding the impact of gut microbiota on host miRNA expression is primarily derived from miRNA expression profile studies comparing traditional mice with germ-free (GF), or colonized mice. Significant differences in miRNA expression profiles in the colon and ileum was detected between GF mice colonized with gut microbiota from GF mice and specific-pathogen free (SPF) colonized littermates [33]. Fecal miRNA expression patterns also exhibited apparent differences between conventional mice and GF mice [34]. Additionally, fecal miRNA profiles can be deferentially and specially regulated by various colitogenic and non-colitogenic microbiota [34]. The potential target mRNAs of those miRNAs may be involved in regulation of xenobiotic metabolism, intestinal barrier maintainance and regulation of immune system function [33, 34].

Other studies reveal that gut microbiota regulate intestinal miRNA profiles in a highly cell type-specific manner [35]. The miRNA expression patterns of intestinal epithelial stem cell (IESC) are most significantly altered in response to gut microbiota among all intestinal epithelial cell types, with miR-375-3p identified as selectively sensitive to microbiota from IESC [35]. In addition to intestinal miRNA, the expression of fecal miRNA can also be influenced by gut microbiota. Higher abundance of fecal miRNA profiles is detected in GF mice than SPF colonized littermates, and alterations in fecal miRNA expression patterns can be induced by depleting gut microbiota with antibiotic in SPF mice [7, 36].

In vitro studies demonstrate that commensal bacteria induce certain miRNA expression patterns in intestinal epithelial cells or dendritic cells,targeting mRNAs that regulate the innate immune response and barrier function [37, 38]. Adherent-invasive E. coli (AIEC), a pathogen with high prevalence in Crohn's disease, has been shown to up-regulate miRNAs targeting genes responsible for the autophagy response (ATG5 and ATG16L) in mouse enterocytes, which may facilitate AIEC replication and exacerbation of intestinal inflammation [39]. Probiotics including E. coli Nissle 1917, lactobacilli, Lactobacillus rhamnosus GG, Enterococcus faecium NCIMB 10,415, Enteropathogenic E. coli have also been shown to modulate miRNAs in intestinal epithelial cells or immune cells 
thereby altering intestinal immune regulation and barrier function [40-43].

\section{Gut microbiota regulates brain miRNA expression}

A large number of abnormal brain miRNAs implicated in anxiety-like behaviors have been detected in the region of amygdala and prefrontal cortex of GF mice or mice with microbiota depletion by an antibiotic cocktail [44]. Some dysregulated brain miRNAs in GF mice have been shown to be normalized by microbial colonization [44]. Gut microbiota have also been demonstrated to modulate hippocampal miRNA expression associated via kynurenine pathway enzymes which regulate hippocampal development and axon guidance pathway $[45,46]$. A more recent report describes that a microbial product, Bacteroides fragilis lipopolysaccharide (BF-LPS) can act as a neurotoxin via induction of a series of miRNAs targeting genes that regulate synaptic architecture and deficits, amyloidogenesis, and cerebral inflammatory signaling [47]. Some other microbial metabolites including tryptophan, butyrate, acetylcholine, norepinephrine, serotonin, dopamine may also influence miRNA biology indirectly via regulation of astrocyte function and bloodbrain-barrier integrity, or even by altering human behavior via disruption of normal neurotransmitter levels [48]. The gut microbiota-host miRNA interaction is summarized in Tables 1 and 2.

\section{Extracellular vesicles (EVs)}

\section{$\mathrm{EV}$ biogenesis and function}

EVs compromise a variety of endogenous membranousbound nanovesicles released from cells into the extracellular space [49]. EVs can be detected abundantly in bodily fluid and peripheral blood and can be divided into three subtypes according to biogenesis, size, composition, and cargo: apoptotic bodies, micro-vesicles (MVs), and exosomes [49-51]. EVs play a critical role in cell-to-cell communication under both physiological and pathophysiological conditions via transfer of nucleic acids and protein to recipient cells. This delivery system enables intra and inter-species crosstalk including microbiota-host interactions under both physiological and pathophysiological conditions, even without close cellular contact [6].

Exosomes are currently the most well-recognized and described subtype of EVs, characterized by having a diameter of $30-100 \mathrm{~nm}$. They are initially derived from internalization of the cell membrane, which results in accumulation of intraluminal vesicles (ILVs) and formation of multi-vesicular bodies (MVBs) [52]. After fusing with the plasma membrane, the content of MVBs are released into the extracellular space to form mature exosomes. Exosome can be taken up by recipient cells with horizontal transfer of their cargos including DNA, RNA (mRNA, miRNA, non-coding RNA) and proteins [53-55]. Exosomes participate in multiple cellular

Table 1 Gut/fecal miRNA capable of modulating gut microbiota and their function

\begin{tabular}{|c|c|c|c|}
\hline Gut/fecal miRNA & Function & Disease /experimental model & References \\
\hline miR155/let-7 g & Cardiovascular function & Ovariectomized mice & [29] \\
\hline miR-34a-5p & Cognitive impairment & Total abdominal irradiation (mice) & {$[30]$} \\
\hline miR-182, miR-503, mir-17 92 cluster & $\begin{array}{l}\text { Glycan production in recruiting } \\
\text { bacteria to tumor }\end{array}$ & Colorectal cancer (patients) & {$[31]$} \\
\hline $\begin{array}{l}\text { miR-199a, miR-223-3p, miR-1226, miR-548ab, } \\
\text { miR-515-5p }\end{array}$ & $\begin{array}{l}\text { Disease activity and prognosis of } \\
\text { inflammatory bowel disease }\end{array}$ & Inflammatory bowel disease (patients) & {$[32]$} \\
\hline
\end{tabular}

Table 2 Gut or brain miRNA modulated by gut microbiota/microbial products and their function

\begin{tabular}{|c|c|c|c|}
\hline miRNA & Cell /tissue/organ & Function & References \\
\hline miR10-a & Dendritic Cell & Innate immune responses & {$[37]$} \\
\hline miR-21-5p & Intestinal epithelial cells & Intestinal epithelial barrier & {$[38]$} \\
\hline miR-30c,miR-130A & Enterocyte & Autophagy response & {$[39]$} \\
\hline miR-203, miR-483-3, miR-595 & Intestinal epithelial cells & Intestinal epithelial barrier & {$[40]$} \\
\hline miR $-423-5 p$ & Intestinal epithelial cells & Immune responses & {$[41]$} \\
\hline miR-155, miR-223 & Colon & Intestinal epithelial barrier & {$[42]$} \\
\hline miR-146a & $\begin{array}{l}\text { Intestinal epithelial and monocytic } \\
\text { Cells }\end{array}$ & Intestinal inflammation & {$[43]$} \\
\hline miR-294-5p & Hippocampus & Kynurenine metabolism & {$[45]$} \\
\hline $\begin{array}{l}\text { miR-9, miR-34a, miR-125b, miR-146a, miR- } \\
\quad 155\end{array}$ & Neuronal-glial cells & Inflammatory neurodegeneration & {$[47]$} \\
\hline
\end{tabular}


process related to gene transcription and translation, transcript and protein modifications, protein localization, and key enzymatic reactions [56-59]. MiRNAs have been detected in exosomes derived from cancer cells, virus-infected cells, and mesenchymal stem cells, playing a fundamental role in intercellular communication via transfer of translational control in various physiological and pathophysiological processes [60-70]. There have been four proposed pathways for sorting miRNAs into exosomes: (1) a neural sphingomyelinase 2 (nSMase2)dependent pathway; (2) a sumoylated heterogeneous nuclear ribonucleoprotein (hnRNP)-dependent pathway; (3) guide dance by the 3' end of the miRNA sequence; and, (4) mediation by the miRNA-induced silencing complex (miRISC) [71-76]. However, controversy remains on the exact composition of EVs secondary and the presence and abundance of EV miRNA and miRNA carriers [77-81].

\section{Influencing factor for EV biogenesis}

The biogenesis of EV is regulated by a variety of intracellular proteins, enzymes and signaling pathways including: (1) RNA-binding proteins such as hnRNPA2B1 and Argonaute-2; (2) membranous proteins such as Caveolin-1 and Neural Sphingomyelinases; (3) Rab GTPases, ARRDC1, and ESCRT complexes; (4) lipid rafts or membrane lipid microdomains; (5) cytosolic proteins (syntenin) and endosomal enzymes (Heparanase); and, 6) Intracellular calcium-signaling pathways [82-89]. Biogenesic processes can also be modulated by different extracellular stimuli including: (1) viral infection; (2) oncogenic transformation or stresses; (3) hypoxia; (4) alcohol exposure; (5) irradiation; (6) impaired autophagy; and, (7) circulating hormones, which all have important implications in elucidating the pathophysiological mechanisms for development of novel therapeutic targets [90-95].

\section{EV entrapment of fecal miRNA}

In their study on fecal miRNA expression profiles, Liu et al. detected EVs in fecal samples and demonstrated that the most abundant fecal miRNAs were also contained within EVs, suggesting that EVs are the major extracellular source of fecal miRNAs [7]. EVs protect fecal miRNAs from degradation via a phospholipid bilayer comprising membrane proteins of EV which entrapping miRNA [96, 97].

\section{Brain-derived EVs}

Recent studies describe a wide distribution of EV in the CNS, detected in oligodendrocytes, neurons, astrocytes, microglia, choroid plexus, and brain epithelial cells the interface of blood-brain barrier (BBB) and cerebrospinal fluid (CSF) [98-100]. Brain-derived EVs play a key role in cell-to-cell communication involved in neurogenesis, neural development, neuro-inflammation, synaptic communication and nerve regeneration [101-104]. Accumulating evidence suggest that brain-derived EVs, especially exosomes, play an important role in the pathogenesis of neurodegenerative diseases, infectious CNS diseases, neuroinflammation, psychiatric disease and brain tumors [105-111].Their output and cargo can be cell-specific and disease -specific and varied with different events during disease progress, features that provide strong potential for use as a biomarker for CNS disease [108, 112, 113]. Furthermore, several other key features of EVs including stability, low immunogenicity, facility of crossing the BBB, accurate cell targeting and specific delivery make them an attractive candidate for therapeutic delivery vehicles in treating CNS disease [114-116].

MiRNAs have been demonstrated to play an important active biological role within brain-derived EVs from astrocytes, neurons, macrophage/microglial cells, prefrontal cortices cells, glioma cells, glioblastoma cells, and glioblastoma stem-like cells, playing a critical role in neurogenesis, response to stress, virus induced neurotoxicity, schizophrenia and bipolar disorder, brain tumor progress, brain metastasis outgrowth [101, 117-120]. More recent research indicates that brain-derived EVs can be detectable in plasma, and astrocyte-derived exosomes are capable of transferring miRNA to metastatic tumor cells, suggesting that brain-derived EVs may transfer molecular information to tissues remote from the CNS [120-122]. Several recent studies have demonstrated that altered miRNA profiles in brain EVs from Alzheimer's patients, however the mechanisms and clinical significance underscoring these observations remain a focus of investigation [123-125]. Critically, the biological relevance for EV transfer from brain to gut has not been fully elucidated.

\section{Microbiota-derived EV}

Bacterial membrane vesicles, including outer-membrane vesicles (OMVs) derived from Gram-negative bacterium and membrane vesicles (MVs) derived from Gram-positive bacteria, parasites, fungi, mycobacteria, refer to a collection of nano-sized membrane vesicles released from bacteria into the extracellular environment $[126,127]$. Bacterial membrane vesicles are currently regarded as microbiota derived-EVs since they share characteristic similarities in size, structure and biological function with EVs derived from mammalian cells [128]. Microbiota-derived EVs can transfer a broad range of cargo including bioactive proteins, lipids, nucleic acids, and virulence factors to neighboring bacteria or host cells (epithelial cells, endothelial cells, immune cells). This bioinformatic transferring plays a 
critical role in cellular processes for both intra-kingdom (bacteria-bacteria) interactions and inter-kingdom (bacteria-host) communications [129, 130]. The effect of microbiota derived EVs can be effectively differentiated from microbial metabolites or host by evaluating the effect of bacterial free microbiota-derived EVs isolated from bacterial cultures on fecal samples [131]. Recent advances in this field reveal that microbiotaderived EVs exhibit multiple regulatory functions central for bacterial survival and nutrient acquisition, bacterial virulence delivery, host colonization and invasion, microbial interactions, antimicrobial resistance, stress and inflammatory response, endothelial cell adhesion, and systemic inflammatory and metabolic response, which all play key roles in the pathogenesis of diverse infectious and inflammatory diseases [132-139]. Several key features of OMV including size, antigen stability, high immunogenicity, accurate host cell targeting, specific cargo delivery and host immune response make them a promising novel candidate for a vaccine target against bacterial infections, and as targeted drug delivery against cancer and other diseases [140-142]. Recent findings have focused on the modulatory effect of microbiota-derived EVs on intestinal barrier function and the immune response, two important components of GBMAx [143-148]. Furthermore, relevant studies also reveal that microbiota-derived EVs can be released into the systemic circulation and cross the BBB $[8,149,150]$. Staphylococcus aureus and Helicobacter pylori-derived EVs have been detected in the brain after oral administration or intramuscular injection via in vivo imaging procedures $[151,152]$. Additionally, LPS, a key virulence factor in porphyromonas gingivalis outer membrane vesicles has been found in glia and the major cerebral vessels of patients with Alzheimers disease (AD) by immunoblot [153]. It has been hypothesized that microbiota-derived EV may be absorbed into mesenteric veins, carried by the hepatic portal vein and liver, to finally enter the brain via the circulatory system [154]. These data strongly suggest that microbiota-derived EVs may exert a direct effect on the CNS and be an important central modulator for GBMAx.

Small RNA (SRNA) within microbiota derived EV can be internalized by host cells and play an important role in host-pathogen interaction. miRNA-sized sRNA and methionine transfer RNA (tRNA) secreted by bacterial OMV (periodontal pathogens and Pseudomonas aeruginos $a$ ) have been shown to enter host cells and modulate host immunity $[155,156]$. EV-contained miRNA secreted by gastrointestinal nematode has been detected in circulation, which can be internalized by small intestinal epithelial cells and modulate host innate response [157].
Microbiota derived RNA may act as ligands for Toll-like Receptor (TLR) and regulators for host innate immunity $[158,159]$.

More recent research revealed that OMV may cross the blood-brain barrier and contribute to neuroinflammation and cognitive impairment linked with neurodegeneration disease such as Alzheimer's disease, Parkinson's disease and dementia. The possible mechanism may involve transfer of small RNA non-coding RNA elements contained within OMV into host cells, thereby regulating host gene expression [160-165].

\section{EV derived miRNA in metabolic disease}

Obesity, Metabolic Syndrome and diabetic mellitus are known risk factors for the development of CNS disorders including cerebrovascular disease, neurodegenerative diseases and dementia. Several lines of evidence have revealed that EV derived miRNA originated from gut microbiota, adipose tissue, steatotic hepatocytes, mesenchymal stem/stromal cells (MSC), and pancreatic islets play crucial role in the pathogenesis of those metabolic disease and associated target organ injury [166-171]. Their role and relevance to GBMAXs and cerebral disease remains an area of active investogatyion. The impact of EV derived miRNA on neurological and metabolic disease are summarized in Table 3.

\section{Controversies and challenges}

EV derived miRNA has gain great attention in the research of GBMAx. However, controversies and challenges remain in this fields.

\section{EV classsification and miRNA extraction}

The heterogeneity of EV may be far greater than we have recognized previously. A more complex classification system based on EV proteome, nucleic acid distribution and biological function (rather than only 3 subsets mentioned above) has been predicted1 [172-174]. Practical difficulty may exist in extraction of EV-derived miRNA including (1) tedious and costly procedures of ultracentrifugation and density gradient extraction, and purification; (2) lack of standardization with technological platforms and quantitative assays; (3) non-selective enrichment of specific EV subpopulations or differential cellular origins; and, (4) uncoupling from conventional reverse transcriptase quantitative PCR [175-177]. Novel extraction approach and technological improvements are warranted.

\section{Environmental and human genetic factors}

It must be acknowledged that the regulatory system of EV-derived miRNA on GBMAXs is not restricted to EV or miRNAs originating from gut microbiota, gut or brain. 
Table 3 The impact of EV derived miRNA on neurological and metabolic disease

\begin{tabular}{|c|c|c|c|}
\hline EV sRNA & EV origination & Function & References \\
\hline $\begin{array}{l}\text { hsa-miR-23a-3p, hsa-miR-126-3p, hsa-let-7i-5p, hsa- } \\
\text { miR-151a-3p } \\
\text { (Downregulated) }\end{array}$ & Plasma & Unknown in Alzheimer's disease & [123] \\
\hline $\begin{array}{l}\text { miR-212 and miR-132 } \\
\text { (Downregulated) }\end{array}$ & Neurally derived plasma EV & Unknown in Alzheimer's disease & [124] \\
\hline $\begin{array}{l}\text { miR-23a-3p, miR-223-3p, miR-190a-5p, miR-100-3p, } \\
\text { (Downregulated) }\end{array}$ & Neurally Derived Plasma EV & Unknown in Alzheimer's disease & [125] \\
\hline $\begin{array}{l}\text { miRNA cargo } \\
\text { (periodontal bacteria) }\end{array}$ & $\begin{array}{l}\text { Aggregatibacter actinomy- } \\
\text { cetemcomitans }\end{array}$ & Neuroinflammation in Alzheimer's disease & {$[165]$} \\
\hline $\begin{array}{l}\text { miR-27b, miR-126 } \\
\text { miR-130, miR-296 }\end{array}$ & Pancreatic islets & Beta cell-endothelium cross-talk in diabetes & {$[165]$} \\
\hline $\begin{array}{l}\text { miR- } 221-3 p \\
\text { (up regulated) }\end{array}$ & Perivascular adipose tissue & Vascular remodeling in obesity & {$[168]$} \\
\hline $\begin{array}{l}\text { miR-1 } \\
\text { (up regulated) }\end{array}$ & Steatotic hepatocytes & Atherogenesis in Non-alcoholic fatty liver disease & {$[170]$} \\
\hline $\begin{array}{l}\text { miR-136-3p, miR-4798-5p } \\
\text { miR-12,136, miR-222-3p } \\
\text { (Downregulated) } \\
\text { miR-630, miR-144-3p, miR-143-5p, miR-4787-3p miR- } \\
\quad \text { 769-5p, miR-8074, miR-181a-5p) } \\
\text { (up regulated) }\end{array}$ & Mesenchymal stem cells & $\begin{array}{l}\text { Renal tubular cells senescence in metabolic syn- } \\
\text { drome }\end{array}$ & {$[171]$} \\
\hline
\end{tabular}

Environmental factors (e.g. diet, medications, smoking, environmental contaminants, stress) and human genetics also play a crucial modulatory role in GBMAXs via: (1) secreting miRNA containing EVs; (2) shaping gut microbiota; (3) stimulating microbial metabolic products; and, (4) regulation of miRNA expression and function of the host gut and brain [178-184]. The expression of host miRNA ( fecal miRNA or intestinal epithelial cellderived miRNA) and its associated function is impacted by these host genetic and environmental factors, which will ultimately modulate the composition of metabolite and function of gut microbiota [34, 185, 186]. Those environmental and genetic factors may be considered as an extension of the EV-derived miRNA system for GBMAXs, and should be taken into accounting novel drug development and therapeutic strategies targeting GBMAx.

\section{Non-miRNA RNA biotypes and non-vesicle carriers} miRNA is the most studied extracellular RNA but only constitutes a minor composition of RNA biotype in the EV cargo. Other RNA biotypes including small nucleolar RNA (snoRNA), small nuclear RNA (snRNA), long noncoding RNA (lncRNA), Y RNA may be more abundant in EV cargo [187-189]. EV is not the only RNA carrier for miRNA. Non-vesicular miRNAs presenting as ribonucleoprotein complex have been detected in various fluids and circulation, which are becoming candidates for biomarkers and therapeutic targets [190, 191]. The regulatory systems consisting of non-miRNA RNA biotypes and non-vesicle carriers in GBMAx and their relationship with EV derived miRNA should be explored in further study (Table 4).

\section{Conclusions}

MiRNAs play a potentially critical role in gut microbiotagut interaction and gut microbiota-brain bi-directional communication. EVs can be derived from brain, gut and

Table 4 The work-flow of the literature review

\begin{tabular}{|c|c|}
\hline Topic & References \\
\hline 1.Gut-brain-microbiota axis (GBMAx) & {$[1-4,9-15]$} \\
\hline \multicolumn{2}{|l|}{ 2.microRNA( miRNA) } \\
\hline 2.1.miRNA biogenesis & {$[16-19]$} \\
\hline 2.2.miRNA function & {$[20-28]$} \\
\hline \multicolumn{2}{|l|}{ 3.Gut microbiota-host miRNA interaction } \\
\hline 3.1.gut microbiota-gut miRNA interaction & {$[7,29-43]$} \\
\hline 3.2.gut microbiota-brain miRNA interaction & {$[44-48]$} \\
\hline \multicolumn{2}{|l|}{ 4. Extracellular vesicles (EVs) } \\
\hline 4.1.EV biogenesis & {$[49-55,82-95]$} \\
\hline 4.2.EV function & $\begin{array}{l}\text { [60-81, 172-177, } \\
\text { 166-171, 187- } \\
191]\end{array}$ \\
\hline 4.3.Environmental and genetic influence & {$[178-186]$} \\
\hline 4.4.EV entrapment of fecal miRNA & {$[7,96,97]$} \\
\hline 4.5.Brain- derived EVs & {$[98-125]$} \\
\hline 4.6. Microbiota derived EVs & {$[126-165]$} \\
\hline
\end{tabular}


gut microbiota, coordinating cell-to-cell communication via transfer of miRNAs. We hypothesize that an EVmiRNA system throughout GBMAx could play a central role in exchange of molecular information among gut microbiota, gut and brain. This EV-miRNA based regulatory system is schematically outlined in Fig. 1. However, current research in this field remains in the early stages. Further investigations should be performed to elucidate: (1) the direct effect of brain-derived EVs on gut and gut micribota; (2) the precise regulatory mechanisms of EV miRNA transfer, and their biological function on GBMAx; (3) the functional link between EV-miRNA and other classical neuro-immune-endocrine pathways. Progress in this field will provide new insight into the comprehensive understanding of GBMAx and help advance the clinical development of novel biomarkers and therapeutic target for the variety of diseases associated with GBMAx imbalance.

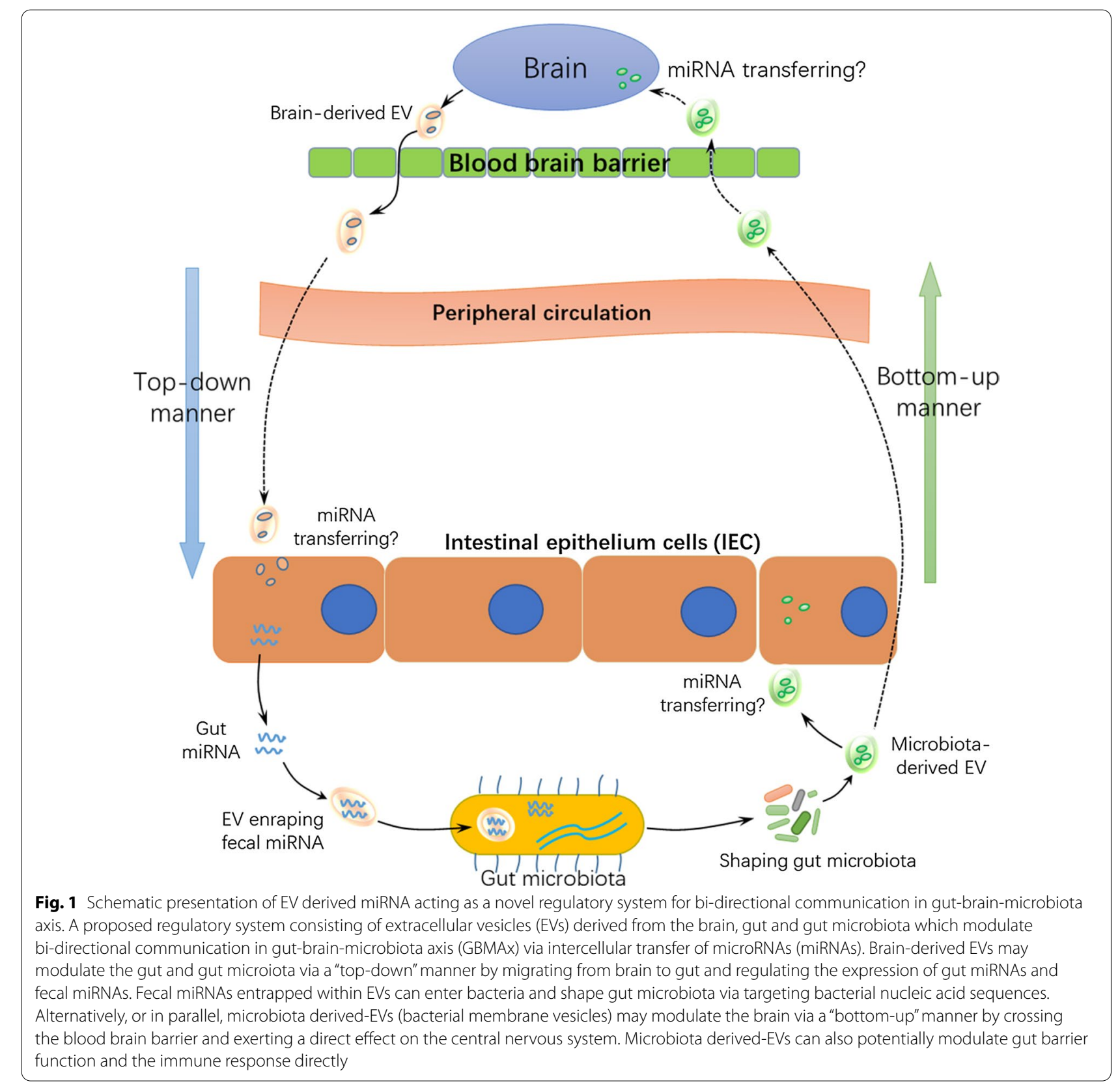




\section{Abbreviations}

GBMAx: Gut-brain-microbiota axis; EVs: Extracellular vesicles; CNS: Central nervous system; ANS: Autonomic nervous system; ENS: And enteric nervous system; HPA: The hypothalamic-pituitary-adrenal axis; pre-miRNA: Primary miRNA transcript; miRISC: MiRNA-associated RNA-induced silencing complex IEC: Intestinal epithelial cells; Hopx: Homeobox gene; OVX: Ovariectomized; TAl: Total abdominal irradiation; GF: Germ-free; SPF: Specific-pathogen free; IESC: Intestinal epithelial stem cell; LGG: Lactobacillus rhamnosus GG; BF-LPS: Bacteroides fragilis lipopolysaccharide; MVs: Micro-vesicles; ILVs: Ntraluminal vesicles; MVBs: Formation of multi-vesicular bodies; AD: Alzheimers disease.

\section{Acknowledgements}

This study was supported by the National Natural Science Foundation of China Nos. 81870939, 81571147 to Dr. Xiong and American Heart Association award 14FTF19970029 to Dr. Stary.

\section{Authors' contributions}

LZ wrote the initial draft. YZY contribute to collecting literature. Figures and submission prepared by $L J G, Z H J$ prepared the final version. CMS and XXX recommended a structure for the review, substantially advanced the draft. All authors read and approved the final manuscript.

\section{Funding}

This study was supported by the National Natural Science Foundation of China No. 81571147 to Dr. Xiong and American Heart Association award 14FTF19970029 to Dr. Stary.

\section{Availability of data and materials}

Not applicable.

\section{Declarations}

\section{Ethics approval and consent to participate:}

Not applicable.

\section{Consent for publication}

Not applicable.

\section{Competing interests}

The authors declare that they have no competing interests.

\section{Author details}

${ }^{1}$ Department of Gastroenterology, Renmin Hospital of Wuhan University, Wuhan, China. ${ }^{2}$ Central Laboratory, Renmin Hospital of Wuhan University, Wuhan, China. ${ }^{3}$ Department of Anesthesiology, Perioperative and Pain Medicine, Stanford University School of Medicine, Stanford, CA 94305, USA.

\section{Received: 30 November 2019 Accepted: 27 November 2020} Published online: 11 May 2021

\section{References}

1. Beaumont W. Nutrition classics. Experiments and observations on the gastric juice and the physiology of digestion By william Beaumont. Plattsburgh. Printed by f. P. Allen. 1833. Nutr Rev. 1977;35:144-5.

2. Al Omran Y, Aziz Q. The brain-gut axis in health and disease. Adv Exp Med Biol. 2014;817:135-53.

3. CANNON. The influence of emotional states on the functions of the alimentary canal. Sciences. 1909;137:480-486

4. Mayer EA, Tillisch K, Gupta A. Gut/brain axis and the microbiota. J Clin Invest. 2015;125:926-38.

5. Zhou G, Zhou Y, Chen X. New insight into inter-kingdom communication: horizontal transfer of mobile small RNAs. Front Microbiol. 2017;1(8):768

6. Van Niel G, D'Angelo G, Raposo G. Shedding light on the cell biology of extracellular vesicles. Nat Rev Mol Cell Biol. 2018;19(4):213-28.

7. Liu S, da Cunha AP, Rezende RM, Cialic R, Wei Z, Bry L, et al. The host shapes the gut microbiota via fecal microrna. Cell Host Microbe. 2016:19:32-43.
8. Ahmadi Badi S, Moshiri A, Fateh A, Rahimi Jamnani F, Sarshar M, Vaziri F, Siadat SD. Microbiota-derived extracellular vesicles as new systemic regulators. Front Microbiol. 2017;24(8):1610.

9. Maloy KJ, Powrie F. Intestinal homeostasis and its breakdown in inflammatory bowel disease. Nature. 2011;474(7351):298-306.

10. Dolapcioglu C, Dolapcioglu H. Structural brain lesions in inflammatory bowel disease. World J Gastrointest Pathophysiol. 2015:6:124-30.

11. Foster JA, McVey Neufeld KA. Gut-brain axis: how the microbiome influences anxiety and depression. Trends Neurosci. 2013:36(5):305-12.

12. Matteoli G, Boeckxstaens GE. The vagal innervation of the gut and immune homeostasis. Gut. 2013;62(8):1214-22.

13. Pott J, Hornef M. Innate immune signalling at the intestinal epithelium in homeostasis and disease. EMBO Rep. 2012;13(8):684-98.

14. Bercik P, Park AJ, Sinclair D, Khoshdel A, Lu J, Huang X, et al. The anxiolytic effect of bifidobacterium longum ncc3001 involves vagal pathways for gut-brain communication. Neurogastroenterol Motil. 2011;23:1132-9.

15. Martin CR, Osadchiy V, Kalani A, Mayer EA. The Brain-gut-microbiome axis. Cell Mol Gastroenterol Hepatol. 2018;6(2):133-48.

16. Bartel DP. MicroRNAs: target recognition and regulatory functions. Cell. 2009;136(2):215-33

17. Bartel DP. Metazoan microRNAs. Cell. 2018;173(1):20-51.

18. Kim VN, Han J, Siomi MC. Biogenesis of small RNAs in animals. Nat Rev Mol Cell Biol. 2009;10(2):126-39.

19. Bartel DP. Micrornas: genomics, biogenesis, mechanism, and function Cell. 2004;116:281-97.

20. Iorio MV, Croce CM. Causes and consequences of microRNA dysregulation. Cancer J. 2012;18(3):215-22.

21. Pratt AJ, MacRae IJ. The rna-induced silencing complex: a versatile gene-silencing machine. J Biol Chem. 2009;284:17897-901.

22. Croce CM. Causes and consequences of microrna dysregulation in cancer. Nat Rev Genet. 2009;10:704-14.

23. Li LC, Okino ST, Zhao H, Pookot D, Place RF, Urakami S, Enokida H, Dahiya R. Small dsRNAs induce transcriptional activation in human cells. Proc Natl Acad Sci USA. 2006;103(46):17337-42.

24. Janowski BA, Younger ST, Hardy DB, Ram R, Huffman KE, Corey DR. Activating gene expression in mammalian cells with promoter-targeted duplex RNAs. Nat Chem Biol. 2007:3(3):166-73.

25. Vasudevan S, Tong Y, Steitz JA. Switching from repression to activation: microRNAs can up-regulate translation. Science. 2007;318(5858):1931-4.

26. Park CY, Choi YS, McManus MT. Analysis of microRNA knockouts in mice Hum Mol Genet. 2010;19(R2):R169-75.

27. Gao L, Jiang F. Microrna (mirna) profiling. Methods Mol Biol. 2016;1381:151-61.

28. Esteller M. Non-coding RNAs in human disease. Nat Rev Genet. 2011:12(12):861-74

29. Diaz-Garrido N, Cordero C, Olivo-Martinez Y, Badia J, Baldomà L. Cell-tocell communication by host-released extracellular vesicles in the gut: implications in health and disease. Int J Mol Sci. 2021;22(4):2213.

30. Cui M, Xiao H, Li Y, Dong J, Luo D, Li H, Feng G, Wang H, Fan S. Total abdominal irradiation exposure impairs cognitive function involving miR-34a-5p/BDNF axis. Biochim Biophys Acta Mol Basis Dis. 2017;1863(9):2333-41.

31. Yuan C, Burns MB, Subramanian S, Blekhman R. Interaction between Host MicroRNAs and the gut microbiota in colorectal cancer. mSystems. 2018;3(3):e00205-17.

32. Ji Y, Li X, Zhu Y, Li N, Zhang N, Niu M. Faecal microRNA as a biomarker of the activity and prognosis of inflammatory bowel diseases. Biochem Biophys Res Commun. 2018:503(4):2443-50.

33. Dalmasso G, Nguyen HT, Yan Y, Laroui H, Charania MA, Ayyadurai S, Sitaraman SV, Merlin D. Microbiota modulate host gene expression via microRNAs. PLOS ONE. 2011;6(4):e19293.

34. Viennois E, Chassaing B, Tahsin A, Pujada A, Wang L, Gewirtz AT, et al. Host-derived fecal micrornas can indicate gut microbiota healthiness and ability to induce inflammation. Theranostics. 2019;9:4542-57.

35. Peck BC, Mah AT, Pitman WA, Ding S, Lund PK, Sethupathy P. Functional transcriptomics in diverse intestinal epithelial cell types reveals robust microRNA sensitivity in intestinal stem cells to microbial status. J Biol Chem. 2017;292(7):2586-600. 
36. Moloney GM, Viola MF, Hoban AE, Dinan TG, Cryan JF. Faecal microRNAs: indicators of imbalance at the host-microbe interface? Benef Microbes. 2018;9(2):175-83.

37. Xue X, Feng T, Yao S, Wolf KJ, Liu CG, Liu X, Elson CO, Cong Y. Microbiota downregulates dendritic cell expression of miR-10a, which targets IL-12/IL-23p40. J Immunol. 2011;187(11):5879-86

38. Nakata K, Sugi Y, Narabayashi H, Kobayakawa T, Nakanishi Y, Tsuda M Hosono A, Kaminogawa S, Hanazawa S, Takahashi K. Commensal microbiota-induced microRNA modulates intestinal epithelial permeability through the small GTPase ARF4. J Biol Chem. 2017;292(37):15426-33.

39. Dalmasso G, Nguyen HTT, Faïs T, Massier S, Barnich N, Delmas J, Bonnet R. Crohn's disease-associated adherent-invasive Escherichia coli manipulate host autophagy by impairing SUMOylation. Cells. 2019;8(1):35.

40. Veltman K, Hummel S, Cichon C, Sonnenborn U, Schmidt MA. Identification of specific miRNAs targeting proteins of the apical junctional complex that simulate the probiotic effect of E. coli Nissle 1917 on T84 epithelial cells. Int J Biochem Cell Biol. 2012;44(2):341-9.

41. Sabharwal H, Cichon C, Ölschläger TA, Sonnenborn U, Schmidt MA. Interleukin-8, CXCL1, and MicroRNA miR-146a Responses to Probiotic Escherichia coli Nissle 1917 and Enteropathogenic E. coli in Human Intestinal Epithelial T84 and Monocytic THP-1 Cells after Apical or Basolateral Infection. Infect Immun. 2016;84(9):2482-92.

42. Kreuzer-Redmer S, Bekurtz JC, Arends D, Bortfeldt R, Kutz-Lohroff B, Sharbati S, et al. Feeding of enterococcus faecium ncimb 10415 leads to intestinal mirna-423-5p-induced regulation of immune-relevant genes. Appl Environ Microbiol. 2016;82:2263-9.

43. Rodriguez-Nogales A, Algieri F, Garrido-Mesa J, Vezza T, Utrilla MP, Chueca N, et al. Differential intestinal anti-inflammatory effects of lactobacillus fermentum and lactobacillus salivarius in dss mouse colitis: Impact on micrornas expression and microbiota composition. Mol Nutr Food Res. 2017:61:1.

44. Hoban AE, Stilling RM, Moloney RD, Shanahan F, Dinan TG, et al. Microbial regulation of microrna expression in the amygdala and prefrontal cortex. Microbiome. 2017;5:102.

45. Moloney GM, O'Leary OF, Salvo-Romero E, Desbonnet L, Shanahan F, Dinan TG, et al. Microbial regulation of hippocampal mirna expression: Implications for transcription of kynurenine pathway enzymes. Behav Brain Res. 2017:334:50-4.

46. Chen JJ, Zeng BH, Li WW, Zhou CJ, Fan SH, Cheng K, et al. Effects of gut microbiota on the microrna and mrna expression in the hippocampus of mice. Behav Brain Res. 2017;322:34-41.

47. Hoban AE, Stilling RM, Moloney G, Moloney RD, Shanahan F, Dinan TG, Cryan JF, Clarke G. Microbial regulation of microRNA expression in the amygdala and prefrontal cortex. Microbiome. 2017;5(1):102.

48. Kumar M, Singh P, Murugesan S, Vetizou M, McCulloch J, Badger JH, et al. Microbiome as an immunological modifier. In: Thurin M, Cesano A, Marincola FM, editors., et al., Biomarkers for immunotherapy of cancer: Methods and protocols. New York: Springer; 2020. p. 595-638.

49. Raposo G, Stoorvogel W. Extracellular vesicles: exosomes, microvesicles, and friends. J Cell Biol. 2013;200(4):373-83.

50. Akers JC, Gonda D, Kim R, Carter BS, Chen CC. Biogenesis of extracelIular vesicles (ev): exosomes, microvesicles, retrovirus-like vesicles, and apoptotic bodies. J Neurooncol. 2013;113:1-11.

51. Taylor DD, Zacharias W, Gercel-Taylor C. Exosome isolation for proteomic analyses and RNA profiling. Methods Mol Biol. 2011;728:235-46.

52. Matsuo H, Chevallier J, Mayran N, Le Blanc I, Ferguson C, Fauré J, Blanc NS, Matile S, Dubochet J, Sadoul R, Parton RG, Vilbois F, Gruenberg J. Role of LBPA and Alix in multivesicular liposome formation and endosome organization. Science. 2004;303(5657):531-4

53. Pant $\mathrm{S}$, Hilton $\mathrm{H}$, Burczynski ME. The multifaceted exosome: biogenesis, role in normal and aberrant cellular function, and frontiers for pharmacological and biomarker opportunities. Biochem Pharmacol. 2012;83(11):1484-94.

54. Colombo M, Raposo G, Théry C. Biogenesis, secretion, and intercellular interactions of exosomes and other extracellular vesicles. Annu Rev Cell Dev Biol. 2014:30:255-89.

55. Abels ER, Breakefield XO. Introduction to extracellular vesicles: biogenesis, RNA cargo selection, content, release, and uptake. Cell Mol Neurobiol. 2016;36(3):301-12.

56. Yoon YJ, Kim OY, Gho YS. Extracellular vesicles as emerging intercellular communicasomes. BMB Rep. 2014:47(10):531-9.
57. Zomer A, Maynard C, Verweij FJ, Kamermans A, Schäfer R, Beerling E, Schiffelers RM, de Wit E, Berenguer J, Ellenbroek SIJ, Wurdinger T, Pegtel DM, van Rheenen J. In Vivo imaging reveals extracellular vesicle-mediated phenocopying of metastatic behavior. Cell. 2015;161(5):1046-57.

58. Keerthikumar S, Chisanga D, Ariyaratne D, Al Saffar H, Anand S, Zhao K, Samuel M, Pathan M, Jois M, Chilamkurti N, Gangoda L, Mathivanan S. ExoCarta: a web-based compendium of exosomal cargo. J Mol Biol. 2016;428(4):688-92.

59. Hoshino A, Costa-Silva B, Shen TL, Rodrigues G, Hashimoto A, Tesic Mark M, Molina H, Kohsaka S, Di Giannatale A, Ceder S, Singh S, Williams C, Soplop N, Uryu K, Pharmer L, King T, Bojmar L, Davies AE, Ararso Y, Zhang T, Zhang H, Hernandez J, Weiss JM, Dumont-Cole VD, Kramer K, Wexler LH, Narendran A, Schwartz GK, Healey JH, Sandstrom P, Labori KJ, Kure EH, Grandgenett PM, Hollingsworth MA, de Sousa M, Kaur S, Jain M, Mallya K, Batra SK, Jarnagin WR, Brady MS, Fodstad O, Muller V, Pantel K, Minn AJ, Bissell MJ, Garcia BA, Kang Y, Rajasekhar VK, Ghajar CM, Matei I, Peinado H, Bromberg J, Lyden D. Tumour exosome integrins determine organotropic metastasis. Nature. 2015;527(7578):329-35.

60. Sastre B, Cañas JA, Rodrigo-Muñoz JM, Del Pozo V. Novel Modulators of Asthma and Allergy: Exosomes and MicroRNAs. Front Immunol. 2017;21(8):826

61. Blandford SN, Galloway DA, Moore CS. The roles of extracellular vesicle microRNAs in the central nervous system. Glia. 2018;66(11):2267-78.

62. Chen JJ, Zhao B, Zhao J, Li S. Potential roles of exosomal MicroRNAs as diagnostic biomarkers and therapeutic application in Alzheimer's disease. Neural Plast. 2017;2017:7027380.

63. Liang $X$, Zhang L, Wang S, Han Q, Zhao RC. Exosomes secreted by mesenchymal stem cells promote endothelial cell angiogenesis by transferring miR-125a. J Cell Sci. 2016;129(11):2182-9.

64. Maemura T, Fukuyama S, Sugita Y, Lopes TJS, Nakao T, Noda T, Kawaoka Y. Lung-derived exosomal miR-483-3p regulates the innate immune response to influenza virus infection. J Infect Dis. 2018;217(9):1372-82.

65. Salehi M, Sharifi M. Exosomal miRNAs as novel cancer biomarkers: challenges and opportunities. J Cell Physiol. 2018;233(9):6370-80.

66. Wang S, Wang JQ, LV XW. Exosomal miRNAs as biomarkers in the diagnosis of liver disease. Biomark Med. 2017;11(6):491-501.

67. Qiu G, Zheng G, Ge M, Wang J, Huang R, Shu Q. Mesenchymal stem cell-derived extracellular vesicles affect disease outcomes via transfer of micrornas. Stem Cell Res Ther. 2018;9:320.

68. Wang M, Yu F, Ding H, Wang Y, Li P, Wang K. Emerging function and clinical values of exosomal micrornas in cancer. Mol Ther Nucleic Acids. 2019;16:791-804.

69. Yoshikawa FSY, Teixeira FME, Sato MN, Oliveira L. Delivery of micrornas by extracellular vesicles in viral infections: could the news be packaged? Cells. 2019;8:1.

70. Valadi H, Ekstrom K, Bossios A, Sjostrand M, Lee JJ, Lotvall JO. Exosomemediated transfer of mrnas and micrornas is a novel mechanism of genetic exchange between cells. Nat Cell Biol. 2007;9:654-9.

71. Gibbings DJ, Ciaudo C, Erhardt M, Voinnet O. Multivesicular bodies associate with components of miRNA effector complexes and modulate miRNA activity. Nat Cell Biol. 2009;11(9):1143-9.

72. Koppers-Lalic D, Hackenberg M, Bijnsdorp IV, van Eijndhoven MAJ, Sadek P, Sie D, Zini N, Middeldorp JM, Ylstra B, de Menezes RX, Würdinger T, Meijer GA, Pegtel DM. Nontemplated nucleotide additions distinguish the small RNA composition in cells from exosomes. Cell Rep. 2014;8(6):1649-58.

73. Kosaka N, Iguchi H, Hagiwara K, Yoshioka Y, Takeshita F, Ochiya T. Neutral sphingomyelinase 2 (nSMase2)-dependent exosomal transfer of angiogenic microRNAs regulate cancer cell metastasis. J Biol Chem. 2013;288(15):10849-59.

74. Lee YS, Pressman S, Andress AP, Kim K, White JL, Cassidy JJ, Li X, Lubell K, Lim DH, Cho IS, Nakahara K, Preall JB, Bellare P, Sontheimer EJ, Carthew RW. Silencing by small RNAs is linked to endosomal trafficking. Nat Cell Biol. 2009;11(9):1150-6.

75. Villarroya-Beltri C, Gutiérrez-Vázquez C, Sánchez-Cabo F, Pérez-Hernández D, Vázquez J, Martin-Cofreces N, Martinez-Herrera DJ, PascualMontano A, Mittelbrunn M, Sánchez-Madrid F. Sumoylated hnRNPA2B1 controls the sorting of miRNAs into exosomes through binding to specific motifs. Nat Commun. 2013;4:2980. 
76. Zhang J, Li S, Li L, Li M, Guo C, Yao J, Mi S. Exosome and exosomal microRNA: trafficking, sorting, and function. Genomics Proteomics Bioinform. 2015;13(1):17-24.

77. Sluijter JPG, Davidson SM, Boulanger CM, Buzás El, de Kleijn DPV, Enge FB, Giricz Z, Hausenloy DJ, Kishore R, Lecour S, Leor J, Madonna R, Perrino C, Prunier F, Sahoo S, Schiffelers RM, Schulz R, Van Laake LW, Ytrehus K, Ferdinandy P. Extracellular vesicles in diagnostics and therapy of the ischaemic heart: Position Paper from the Working Group on Cellular Biology of the Heart of the European Society of Cardiology. Cardiovasc Res. 2018;114(1):19-34.

78. Coumans FAW, Brisson AR, Buzas El, Dignat-George F, Drees EEE El-Andaloussi S, Emanueli C, Gasecka A, Hendrix A, Hill AF, Lacroix R, Lee Y, van Leeuwen TG, Mackman N, Mäger I, Nolan JP, van der Pol E, Pegtel DM, Sahoo S, Siljander PRM, Sturk G, de Wever O, Nieuwland R. Methodological guidelines to study extracellular vesicles. Circ Res. 2017;120(10):1632-48

79. Ridger VC, Boulanger CM, Angelillo-Scherrer A, Badimon L, Blanc-Brude O, Bochaton-Piallat ML, Boilard E, Buzas El, Caporali A, Dignat-George F, Evans PC, Lacroix R, Lutgens E, Ketelhuth DFJ, Nieuwland R, Toti F, Tunon J, Weber C, Hoefer IE. Microvesicles in vascular homeostasis and diseases Position Paper of the European Society of Cardiology (ESC) Working Group on Atherosclerosis and Vascular Biology. Thromb Haemost. 2017;117(7):1296-316

80. Wang T, Turko IV. Proteomic toolbox to standardize the separation of extracellular vesicles and lipoprotein particles. J Proteome Res. 2018;17(9):3104-13.

81. Simonsen JB. What are we looking at? Extracellular vesicles, lipoproteins, or both? Circ Res. 2017;121(8):920-2.

82. Rothberg KG, Heuser JE, Donzell WC, Ying YS, Glenney JR, Anderson RG. Caveolin, a protein component of caveolae membrane coats. Cell. 1992;68:673-82

83. Baietti MF, Zhang Z, Mortier E, Melchior A, Degeest G, Geeraerts A, et al. Syndecan-syntenin-alix regulates the biogenesis of exosomes. Nat Cell Biol. 2012;14:677-85.

84. Li B, Antonyak MA, Zhang J, Cerione RA. Rhoa triggers a specific signaling pathway that generates transforming microvesicles in cancer cells. Oncogene. 2012;31:4740-9.

85. Verderio C, Gabrielli M, Giussani P. Role of sphingolipids in the biogenesis and biological activity of extracellular vesicles. J Lipid Res. 2018;59:1325-40.

86. Russell AE, Sneider A, Witwer KW, Bergese P, Bhattacharyya SN, Cocks $A$, et al. Biological membranes in ev biogenesis, stability, uptake, and cargo transfer: An isev position paper arising from the isev membranes and evs workshop. J Extracell Vesicles. 2019;8:1684862.

87. Taylor J, Azimi I, Monteith G, Bebawy M. Ca(2+) mediates extracellular vesicle biogenesis through alternate pathways in malignancy. J Extracell Vesic. 2020;9:1734326-1734326.

88. David G, Zimmermann P. Heparanase involvement in exosome formation. Adv Exp Med Biol. 2020;1221:285-307.

89. Groot M, Lee H. Sorting mechanisms for micrornas into extracellular vesicles and their associated diseases. Cells. 2020;9:1.

90. McNamara RP, Costantini LM, Myers TA, Schouest B, Maness NJ, Griffith JD, et al. Nef secretion into extracellular vesicles or exosomes is conserved across human and simian immunodeficiency viruses. mBio. 2018;9:1.

91. Jones LB, Kumar S, Curry AJ, Price JS, Krendelchtchikov A, Crenshaw $\mathrm{BJ}$, et al. Alcohol exposure impacts the composition of hela-derived extracellular vesicles. Biomedicines. 2019;7:1.

92. Jabbari N, Karimipour M, Khaksar M, Akbariazar E, Heidarzadeh M, Mojarad B, et al. Tumor-derived extracellular vesicles: Insights into bystander effects of exosomes after irradiation. Lasers Med Sci. 2020;35:531-45.

93. Kumar A, Deep G. Hypoxia in tumor microenvironment regulates exosome biogenesis: molecular mechanisms and translational opportunities. Cancer Lett. 2020;479:23-30.

94. Gallart-Palau X, Guo X, Serra A, Sze SK. Alzheimer's disease progression characterized by alterations in the molecular profiles and biogenesis of brain extracellular vesicles. Alzheimers Res Ther. 2020;12:54.

95. Nakamura Y, Kita S, Tanaka Y, Fukuda S, Obata Y, Okita T, et al. Adiponectin stimulates exosome release to enhance mesenchymal stem-celldriven therapy of heart failure in mice. Mol Ther. 2020;28(10):2203-19.
96. Creemers EE, Tijsen AJ, Pinto YM. Circulating microRNAs: novel biomarkers and extracellular communicators in cardiovascular disease? Circ Res. 2012;110(3):483-95.

97. Williams MR, Stedtfeld RD, Tiedje JM, Hashsham SA. MicroRNAs-based inter-domain communication between the host and members of the gut microbiome. Front Microbiol. 2017;27(8):1896.

98. Pegtel DM, Peferoen L, Amor S. Extracellular vesicles as modulators of cell-to-cell communication in the healthy and diseased brain. Philos Trans R Soc Lond B Biol Sci. 2014;369(1652):20130516.

99. Antonucci F, Turola E, Riganti L, Caleo M, Gabrielli M, Perrotta C, Novellino L, Clementi E, Giussani P, Viani P, Matteoli M, Verderio C. Microvesicles released from microglia stimulate synaptic activity via enhanced sphingolipid metabolism. EMBO J. 2012;31(5):1231-40.

100. Fröhlich D, Kuo WP, Frühbeis C, Sun JJ, Zehendner CM, Luhmann HJ, Pinto S, Toedling J, Trotter J, Krämer-Albers EM. Multifaceted effects of oligodendroglial exosomes on neurons: impact on neuronal firing rate, signal transduction and gene regulation. Philos Trans R Soc Lond B Biol Sci. 2014;369(1652):20130510.

101. Luarte A, Cisternas P, Caviedes A, Batiz LF, Lafourcade C, Wyneken U, Henzi R. Astrocytes at the hub of the stress response: potential modulation of neurogenesis by miRNAs in astrocyte-derived exosomes. Stem Cells Int. 2017;2017:1719050.

102. Budnik V, Ruiz-Cañada C, Wendler F. Extracellular vesicles round off communication in the nervous system. Nat Rev Neurosci. 2016;17(3):160-72.

103. Balusu S, Van Wonterghem E, De Rycke R, Raemdonck K, Stremersch S, Gevaert K, Brkic M, Demeestere D, Vanhooren V, Hendrix A, Libert C, Vandenbroucke RE. Identification of a novel mechanism of blood-brain communication during peripheral inflammation via choroid plexusderived extracellular vesicles. EMBO Mol Med. 2016;8(10):1162-83.

104. Park S, Ahn ES, Kim Y. Neuroblastoma SH-SY5Y cell-derived exosomes stimulate dendrite-like outgrowths and modify the differentiation of A375 melanoma cells. Cell Biol Int. 2015;39(4):379-87.

105. Trotta T, Panaro MA, Cianciulli A, Mori G, Di Benedetto A, Porro C. Microglia-derived extracellular vesicles in alzheimer's disease: A doubleedged sword. Biochem Pharmacol. 2018;148:184-92.

106. Welton JL, Loveless S, Stone T, von Ruhland C, Robertson NP, Clayton A. Cerebrospinal fluid extracellular vesicle enrichment for protein biomarker discovery in neurological disease; multiple sclerosis. J Extracell Vesicles. 2017;6(1):1369805

107. Figueroa JM, Skog J, Akers J, Li H, Komotar R, Jensen R, Ringel F, Yang I, Kalkanis S, Thompson R, LoGuidice L, Berghoff E, Parsa A, Liau L, Curry W, Cahill D, Bettegowda C, Lang FF, Chiocca EA, Henson J, Kim R, Breakefield X, Chen C, Messer K, Hochberg F, Carter BS. Detection of wild-type EGFR amplification and EGFRvIII mutation in CSFderived extracellular vesicles of glioblastoma patients. Neuro Oncol. 2017;19(11):1494-502.

108. Kawikova I, Askenase PW. Diagnostic and therapeutic potentials of exosomes in CNS diseases. Brain Res. 2015;18(1617):63-71.

109. Osier N, Motamedi V, Edwards K, Puccio A, Diaz-Arrastia R, Kenney K, Gill J. Exosomes in acquired neurological disorders: new insights into pathophysiology and treatment. Mol Neurobiol. 2018;55(12):9280-93.

110. Ciregia F, Urbani A, Palmisano G. Extracellular vesicles in brain tumors and neurodegenerative diseases. Front Mol Neurosci. 2017;31(10):276

111. Lee Y, Park JY, Lee EH, Yang J, Jeong BR, Kim YK, Seoh JY, Lee S, Han PL, Kim EJ. Rapid assessment of microbiota changes in individuals with autism spectrum disorder using bacteria-derived membrane vesicles in urine. Exp Neurobiol. 2017;26(5):307-17.

112. Rufino-Ramos D, Albuquerque PR, Carmona V, Perfeito R, Nobre RJ, Almeida L. Extracellular vesicles: Novel promising delivery systems for therapy of brain diseases. J Control Release. 2017;262:247-58.

113. Yuan D, Zhao Y, Banks WA, Bullock KM, Haney M, Batrakova E, Kabanov AV. Macrophage exosomes as natural nanocarriers for protein delivery to inflamed brain. Biomaterials. 2017;142:1-12.

114. Murgoci AN, Cizkova D, Majerova P, Petrovova E, Medvecky L, Fournier I, Salzet M. Brain-cortex microglia-derived exosomes: nanoparticles for glioma therapy. ChemPhysChem. 2018;19(10):1205-14.

115. Venkat P, Chen J, Chopp M. Exosome-mediated amplification of endogenous brain repair mechanisms and brain and systemic organ interaction in modulating neurological outcome after stroke. J Cereb Blood Flow Metab. 2018;38(12):2165-78. 
116. Otero-Ortega L, de Frutos MC, Laso-García F, Rodríguez-Frutos B, Medina-Gutiérrez E, López JA, Vázquez J, Díez-Tejedor E, GutiérrezFernández M. Exosomes promote restoration after an experimental animal model of intracerebral hemorrhage. J Cereb Blood Flow Metab. 2018;38(5):767-79.

117. Yelamanchili SV, Lamberty BG, Rennard DA, Morsey BM, Hochfelder CG, Meays BM, Levy E, Fox HS. Correction: MiR-21 in extracellular vesicles leads to neurotoxicity via TLR7 signaling in SIV neurological Disease. PLoS Pathog. 2018:14(5):e1007068.

118. Banigan MG, Kao PF, Kozubek JA, Winslow AR, Medina J, Costa J, Schmitt A, Schneider A, Cabral H, Cagsal-Getkin O, Vanderburg CR, Delalle I. Differential expression of exosomal microRNAs in prefrontal cortices of schizophrenia and bipolar disorder patients. PLOS ONE. 2013;8(1):e48814.

119. Yang JK, Yang JP, Tong J, Jing SY, Fan B, Wang F, Sun GZ, Jiao BH. Exosomal miR-221 targets DNM3 to induce tumor progression and temozolomide resistance in glioma. J Neurooncol. 2017;131(2):255-65.

120. Zhang L, Zhang S, Yao J, Lowery FJ, Zhang Q, Huang WC, Li P, Li M, Wang $\mathrm{X}$, Zhang C, Wang H, Ellis K, Cheerathodi M, McCarty JH, Palmier D, Saunus J, Lakhani S, Huang S, Sahin AA, Aldape KD, Steeg PS, Yu D. Microenvironment-induced PTEN loss by exosomal microRNA primes brain metastasis outgrowth. Nature. 2015;527(7576):100-4.

121. Picciolini S, Gualerzi A, Vanna R, Sguassero A, Gramatica F, Bedoni M, Masserini M, Morasso C. Detection and characterization of different brain-derived subpopulations of plasma exosomes by surface plasmon resonance imaging. Anal Chem. 2018;90(15):8873-80.

122. Patterson SA, Deep G, Brinkley TE. Detection of the receptor for advanced glycation endproducts in neuronally-derived exosomes in plasma. Biochem Biophys Res Commun. 2018;500(4):892-6.

123. Gamez-Valero A, Campdelacreu J, Vilas D, Ispierto L, Rene R, Alvarez R, et al. Exploratory study on microrna profiles from plasma-derived extracellular vesicles in alzheimer's disease and dementia with lewy bodies. Transl Neurodegener. 2019;8:31.

124. Cha DJ, Mengel D, Mustapic M, Liu W, Selkoe DJ, Kapogiannis D, et al. Mir-212 and mir-132 are downregulated in neurally derived plasma exosomes of alzheimer's patients. Front Neurosci. 2019;13:1208.

125. Serpente M, Fenoglio C, D'Anca M, Arcaro M, Sorrentino F, Visconte $C$, et al. Mirna profiling in plasma neural-derived small extracellular vesicles from patients with alzheimer's disease. Cells. 2020;9:1.

126. Chatterjee SN, Das J. Electron microscopic observations on the excretion of cell-wall material by Vibrio cholerae. J Gen Microbiol. 1967:49(1):1-11.

127. Zhou L, Srisatjaluk R, Justus DE, Doyle RJ. On the origin of membrane vesicles in gram-negative bacteria. FEMS Microbiol Lett. 1998;163(2):223-8.

128. Yu YJ, Wang XH, Fan GC. Versatile effects of bacterium-released membrane vesicles on mammalian cells and infectious/inflammatory diseases. Acta Pharmacol Sin. 2018;39:514-33.

129. Yoon H. Bacterial outer membrane vesicles as a delivery system for virulence regulation. J Microbiol Biotechnol. 2016;26(8):1343-7.

130. Pathirana RD, Kaparakis-Liaskos M. Bacterial membrane vesicles: biogenesis, immune regulation and pathogenesis. Cell Microbiol. 2016:18:1518-24

131. Gao XJ, Li T, Wei B, Yan ZX, Hu N, Huang YJ, et al. Bacterial outer membrane vesicles from dextran sulfate sodium-induced colitis differentially regulate intestinal udp-glucuronosyltransferase 1a1 partially through toll-like receptor 4/mitogen-activated protein kinase/phosphatidylinositol 3-kinase pathway. Drug Metab Dispos. 2018;46:292-302.

132. Vanaja SK, Russo AJ, Behl B, Banerjee I, Yankova M, Deshmukh SD, Rathinam VAK. Bacterial outer membrane vesicles mediate cytosolic localization of LPS and caspase-11 activation. Cell. 2016;165(5):1 106-19.

133. Shah B, Sullivan CJ, Lonergan NE, Stanley S, Soult MC, Britt LD. Circulating bacterial membrane vesicles cause sepsis in rats. Shock. 2012;37(6):621-8

134. Kaparakis-Liaskos M, Ferrero RL. Immune modulation by bacterial outer membrane vesicles. Nat Rev Immunol. 2015;15(6):375-87.

135. Crowley JT, Toledo AM, LaRocca TJ, Coleman JL, London E, Benach JL. Lipid exchange between Borrelia burgdorferi and host cells. PLoS Pathog. 2013;9(1):e1003109.
136. Soult MC, Dobrydneva Y, Wahab KH, Britt LD, Sullivan CJ. Outer membrane vesicles alter inflammation and coagulation mediators. J Surg Res. 2014:192(1):134-42.

137. Kim JH, Yoon YJ, Lee J, Choi EJ, Yi N, Park KS, Park J, Lötvall J, Kim YK, Gho YS. Outer membrane vesicles derived from Escherichia coli up-regulate expression of endothelial cell adhesion molecules in vitro and in vivo. PLOS ONE. 2013;8(3):e59276.

138. Jung AL, Stoiber C, Herkt CE, Schulz C, Bertrams W, Schmeck B. Legionella pneumophila-derived outer membrane vesicles promote bacterial replication in macrophages. PLoS Pathog. 2016;12(4):e1005592.

139. Jager J, Keese S, Roessle M, Steinert M, Schromm AB. Fusion of legionella pneumophila outer membrane vesicles with eukaryotic membrane systems is a mechanism to deliver pathogen factors to host cell membranes. Cell Microbiol. 2015;17:607-20.

140. Roberts R, Moreno G, Bottero D, Gaillard ME, Fingermann M, Graieb A, Rumbo M, Hozbor D. Outer membrane vesicles as acellular vaccine against pertussis. Vaccine. 2008;26(36):4639-46.

141. Wang S, Gao J, Wang Z. Outer membrane vesicles for vaccination and targeted drug delivery. Wiley Interdiscip Rev Nanomed Nanobiotechnol. 2019;11(2):e1523.

142. Sierra GV, Campa HC, Varcacel NM, Garcia IL, Izquierdo PL, Sotolongo PF, Casanueva GV, Rico CO, Rodriguez CR, Terry MH. Vaccine against group B Neisseria meningitidis: protection trial and mass vaccination results in Cuba. NIPH Ann. 1991;14(2):195-207 (discussion 208-10).

143. Fábrega MJ, Aguilera L, Giménez R, Varela E, Alexandra Cañas M, Antolín $M$, Badía J, Baldomà L. Activation of immune and defense responses in the intestinal mucosa by outer membrane vesicles of commensal and probiotic Escherichia coli strains. Front Microbiol. 2016;11(7):705.

144. Chelakkot C, Choi Y, Kim DK, Park HT, Ghim J, Kwon Y, Jeon J, Kim MS, Jee YK, Gho YS, Park HS, Kim YK, Ryu SH. Akkermansia muciniphiladerived extracellular vesicles influence gut permeability through the regulation of tight junctions. Exp Mol Med. 2018;50(2):e450.

145. Kang CS, Ban M, Choi EJ, Moon HG, Jeon JS, Kim DK, Park SK, Jeon SG, Roh TY, Myung SJ, Gho YS, Kim JG, Kim YK. Extracellular vesicles derived from gut microbiota, especially Akkermansia muciniphila, protect the progression of dextran sulfate sodium-induced colitis. PLOS ONE. 2013:8(10):e76520.

146. Alvarez CS, Badia J, Bosch M, Giménez R, Baldomà L. Outer membrane vesicles and soluble factors released by probiotic Escherichia coli Nissle 1917 and commensal ECOR63 enhance barrier function by regulating expression of tight junction proteins in intestinal epithelial cells. Front Microbiol. 2016;15(7):1981.

147. Cañas MA, Fábrega MJ, Giménez R, Badia J, Baldomà L. Outer membrane vesicles from probiotic and commensal Escherichia coli activate NOD1-mediated immune responses in intestinal epithelial cells. Front Microbiol. 2018:20(9):498.

148. Gao XJ, LiT, Wei B, Yan ZX, Yan R. Regulatory mechanisms of gut microbiota on intestinal CYP3A and P-glycoprotein in rats with dextran sulfate sodium-induced colitis. Yao Xue Xue Bao. 2017;52(1):34-43.

149. Kelly JR, Kennedy PJ, Cryan JF, Dinan TG, Clarke G, Hyland NP. Breaking down the barriers: the gut microbiome, intestinal permeability and stress-related psychiatric disorders. Front Cell Neurosci. 2015;14(9):392.

150. Muraca M, Putignani L, Fierabracci A, Teti A, Perilongo G. Gut microbiota-derived outer membrane vesicles: under-recognized major players in health and disease? Discov Med. 2015;19(106):343-8.

151. Choi SJ, Kim MH, Jeon J, Kim OY, Choi Y, Seo J, Hong SW, Lee WH, Jeon SG, Gho YS, Jee YK, Kim YK. Active immunization with extracellular vesicles derived from Staphylococcus aureus effectively protects against staphylococcal lung infections, mainly via Th1 cell-mediated immunity. PLOS ONE. 2015;10(9):e0136021.

152. Choi HI, Choi JP, Seo J, Kim BJ, Rho M, Han JK, Kim JG. Helicobacter pylori-derived extracellular vesicles increased in the gastric juices of gastric adenocarcinoma patients and induced inflammation mainly via specific targeting of gastric epithelial cells. Exp Mol Med. 2017:49(5):e330.

153. Singhrao SK, Olsen I. Are porphyromonas gingivalis outer membrane vesicles microbullets for sporadic alzheimer's disease manifestation? Alzheimers Dis Rep. 2018;2:219-28.

154. Choi J, Kim YK, Han PL. Extracellular vesicles derived from lactobacillus plantarum increase bdnf expression in cultured hippocampal neurons 
and produce antidepressant-like effects in mice. Exp Neurobiol. 2019;28:158-71.

155. Koeppen K, Hampton TH, Jarek M, Scharfe M, Gerber SA, Mielcarz DW, et al. A novel mechanism of host-pathogen interaction through srna in bacterial outer membrane vesicles. PLoS Pathog. 2016;12:e1005672-e1005672.

156. Choi JW, Kim SC, Hong SH, Lee HJ. Secretable small rnas via outer membrane vesicles in periodontal pathogens. J Dent Res. 2017;96:458-66.

157. Buck AH, Coakley G, Simbari F, McSorley HJ, Quintana JF, Le Bihan T, et al. Erratum: Exosomes secreted by nematode parasites transfer small rnas to mammalian cells and modulate innate immunity. Nat Commun. 2015;6:8772.

158. Drexler SK, Foxwell BM. The role of toll-like receptors in chronic inflammation. Int J Biochem Cell Biol. 2010;42:506-18.

159. Takeuchi O, Akira S. Pattern recognition receptors and inflammation. Cell. 2010;140:805-20.

160. Sun MF, Shen YQ. Dysbiosis of gut microbiota and microbial metabolites in parkinson's disease. Ageing Res Rev. 2018;45:53-61.

161. Han EC, Choi SY, Lee Y, Park JW, Hong SH, Lee HJ. Extracellular rnas in periodontopathogenic outer membrane vesicles promote tnf- $\mathrm{a}$ production in human macrophages and cross the blood-brain barrier in mice. Faseb J. 2019;33:13412-22.

162. Wei SC, Wei W, Peng WJ, Liu Z, Cai ZY, Zhao B. Metabolic alterations in the outer membrane vesicles of patients with Alzheimer's disease: an lc-ms/ms-based metabolomics analysis. Curr Alzheimer Res. 2019;16:1183-95.

163. Leclair-Visonneau L, Neunlist M, Derkinderen P, Lebouvier T. The gut in parkinson's disease: bottom-up, top-down, or neither? Neurogastroenterol Motil. 2020;32:e13777.

164. Wei S, Peng W, Mai Y, Li K, Wei W, Hu L, et al. Outer membrane vesicles enhance tau phosphorylation and contribute to cognitive impairment. J Cell Physiol. 2020;235:4843-55.

165. Łuc M, Misiak B, Pawłowski M, Stańczykiewicz B, Zabłocka A, Szcześniak $D$, et al. Gut microbiota in dementia Critical review of novel findings and their potential application. Progr Neuro-Psychopharmacol Biol Psychiatry. 2021;104:110039.

166. Figliolini F, Cantaluppi V, De Lena M, Beltramo S, Romagnoli R, Salizzoni $M$, et al. Isolation, characterization and potential role in beta cellendothelium cross-talk of extracellular vesicles released from human pancreatic islets. PLoS ONE. 2014;9:e102521.

167. Fleetwood AJ, Lee MKS, Singleton W, Achuthan A, Lee MC, O'BrienSimpson NM, et al. Metabolic remodeling, inflammasome activation, and pyroptosis in macrophages stimulated by porphyromonas gingivalis and its outer membrane vesicles. Front Cell Infect Microbiol. 2017;7:351.

168. Li X, Ballantyne LL, Yu Y, Funk CD. Perivascular adipose tissue-derived extracellular vesicle mir-221-3p mediates vascular remodeling. FASEB J. 2019;33:12704-22.

169. Seyama M, Yoshida K, Yoshida K, Fujiwara N, Ono K, Eguchi T, et al. Outer membrane vesicles of porphyromonas gingivalis attenuate insulin sensitivity by delivering gingipains to the liver. Biochim Biophys Acta Mol Basis Dis. 2020;1866:165731.

170. Jiang F Chen Q Wang W, Ling Y Yan Y Xia P. Hepatocyte-derived extracellular vesicles promote endothelial inflammation and atherogenesis via microrna-1. J Hepatol. 2020;72:156-66.

171. LiY, Meng Y, Zhu X, Saadiq IM, Jordan KL, Eirin A, et al. Metabolic syndrome increases senescence-associated micro-rnas in extracellular vesicles derived from swine and human mesenchymal stem/stromal cells. Cell Commun Signal. 2020;18:124

172. Kowal J, Arras G, Colombo M, Jouve M, Morath J, Primdal-Bengtson $B$, et al. Proteomic comparison defines novel markers to characterize heterogeneous populations of extracellular vesicle subtypes. Proc Nat Acad Sci USA. 2016;113:1.
173. Zhang H, Freitas D, Kim HS, Fabijanic K, Li Z, Chen H, et al. Identification of distinct nanoparticles and subsets of extracellular vesicles by asymmetric flow field-flow fractionation. Nat Cell Biol. 2018;20:332-43.

174. Choi D, Lee TH, Spinelli C, Chennakrishnaiah S, D'Asti E, Rak J. Extracellular vesicle communication pathways as regulatory targets of oncogenic transformation. Semin Cell Dev Biol. 2017;67:11-22.

175. Zocco D, Zarovni N. Extraction and analysis of extracellular vesicle-associated mirnas following antibody-based extracellular vesicle capture from plasma samples. Methods Mol Biol. 2017:1660:269-85.

176. Kaur S, Abu-Shahba AG, Paananen RO, Hongisto H, Hiidenmaa H, Skottman $\mathrm{H}$, et al. Small non-coding rna landscape of extracellular vesicles from human stem cells. Sci Rep. 2018;8:15503.

177. Lin CW, Jan MS, Kuo JS. The microrna expression profiles in extracellular vesicles from hela cancer cells in response to cationic lipid- or polyethylenimine-mediated gene delivery. J Drug Target. 2019;27:94-102.

178. Goodrich JK, Waters JL, Poole AC, Sutter JL, Koren O, Blekhman R, et al, Human genetics shape the gut microbiome. Cell. 2014;159:789-99.

179. Rothschild D, Weissbrod O, Barkan E, Kurilshikov A, Korem T, Zeevi D, et al. Environment dominates over host genetics in shaping human gut microbiota. Nature. 2018:555:210-5.

180. Teng Y, Ren Y, Sayed M, Hu X, Lei C, Kumar A, et al. Plant-derived exosomal micrornas shape the gut microbiota. Cell Host Microbe. 2018;24:637-52

181. Teodori L, Petrignani I, Giuliani A, Prattichizzo F, Gurău F, Matacchione G, et al. Inflamm-aging micrornas may integrate signals from food and gut microbiota by modulating common signalling pathways. Mech Ageing Devel. 2019;182:111127.

182. Cuevas-Sierra A, Ramos-Lopez O, Riezu-Boj Jl, Milagro FI, Martinez JA. Diet, gut microbiota, and obesity: Links with host genetics and epigenetics and potential applications. Adv Nutr. 2019;10:S17-30.

183. Xing SC, Huang CB, Mi JD, Wu YB, Liao XD. Bacillus coagulans r11 maintained intestinal villus health and decreased intestinal injury in leadexposed mice by regulating the intestinal microbiota and influenced the function of faecal micrornas. Environ Pollut. 2019;255:113139.

184. Neu J. Gut microbiota, host gene expression, and cell traffic via milk. Nestle Nutr Inst Workshop Ser. 2020;94:94-102.

185. Yuan C, Burns MB, Subramanian S, Blekhman R. Interaction between host micrornas and the gut microbiota in colorectal cancer. mSystems. 2018;3:1

186. Yuan C, Subramanian S. Microrna-mediated tumor-microbiota metabolic interactions in colorectal cancer. DNA Cell Biol. 2019;38:281-5.

187. Chevillet JR, Kang Q Ruf IK, Briggs HA, Vojtech LN, Hughes SM, et al. Quantitative and stoichiometric analysis of the microrna content of exosomes. Proc Natl Acad Sci USA. 2014;111:14888-93.

188. Lefebvre FA, Benoit Bouvrette LP, Perras L, Blanchet-Cohen A, Garnier $D$, Rak J, et al. Comparative transcriptomic analysis of human and drosophila extracellular vesicles. Sci Rep. 2016;6:27680.

189. Wei Z, Batagov AO, Schinelli S, Wang J, Wang Y, El Fatimy R, et al. Coding and noncoding landscape of extracellular rna released by human glioma stem cells. Nat Commun. 2017;8:1145.

190. Bryniarski K, Ptak W, Martin E, Nazimek K, Szczepanik M, Sanak $M$, et al. Free extracellular mirna functionally targets cells by transfecting exosomes from their companion cells. PLOS ONE. 2015;10:e0122991-e0122991.

191. Stremersch S, Brans T, Braeckmans K, De Smedt S, Raemdonck K. Nucleic acid loading and fluorescent labeling of isolated extracellular vesicles requires adequate purification. Int J Pharm. 2018;548:783-92.

\section{Publisher's Note}

Springer Nature remains neutral with regard to jurisdictional claims in published maps and institutional affiliations. 